\title{
PSCA expression is associated with favorable tumor features and reduced PSA recurrence in operated prostate cancer
}

\author{
Marie-Christine Heinrich ${ }^{1 \dagger}$, Cosima Göbel ${ }^{1 \dagger}$, Martina Kluth ${ }^{1}$, Christian Bernreuther ${ }^{2}$, Charlotte Sauer ${ }^{1}$, \\ Cornelia Schroeder ${ }^{3}$, Christina Möller-Koop ${ }^{1}$, Claudia Hube-Magg ${ }^{1}$, Patrick Lebok', Eike Burandt ${ }^{1}$, Guido Sauter ${ }^{1}$, \\ Ronald Simon ${ }^{1 *}$ D, Hartwig Huland ${ }^{4}$, Markus Graefen ${ }^{4}$, Hans Heinzer ${ }^{4}$, Thorsten Schlomm ${ }^{4,5}$ and Asmus Heumann ${ }^{3}$
}

\begin{abstract}
Background: Prostate Stem Cell Antigen (PSCA) is frequently expressed in prostate cancer but its exact function is unclear. Methods: To clarify contradictory findings on the prognostic role of PSCA expression, a tissue microarray containing 13,665 prostate cancers was analyzed by immunohistochemistry.

Results: PSCA staining was absent in normal epithelial and stromal cells of the prostate. Membranous and cytoplasmic PSCA staining was seen in $53.7 \%$ of 9642 interpretable tumors. Staining was weak in $22.4 \%$, moderate in $24.5 \%$ and strong in $6.8 \%$ of tumors. PSCA expression was associated with favorable pathological and clinical tumor features: Early pathological tumor stage $(p<0.0001)$, low Gleason grade $(p<0.0001)$, absence of lymph node metastasis $(p<0.0001)$, low pre-operative PSA level $(p=0.0118)$, negative surgical margin $(p<0.0001)$ and reduced PSA recurrence $(p<0.0001)$. PSCA expression was an independent predictor of prognosis in multivariate analysis (hazard ratio 0.84, $p<0.0001$ ).

Conclusions: The absence of statistical relationship to TMPRSS2:ERG fusion status, chromosomal deletion or high tumor cell proliferation argues against a major role of PSCA for regulation of cell cycle or genomic integrity. PSCA expression is linked to favorable prognosis. PSCA measurement is a candidate for inclusion in multi-parametric prognostic prostate cancer tests.
\end{abstract}

Keywords: PSCA, ERG, Tissue microarray, Prostate cancer, Immunohistochemistry

\section{Background}

While most prostate cancers have an indolent clinical course, the disease represents the third most common cause of cancer related death in men in Western societies [1]. Gleason grade and tumor extent on biopsies, preoperative prostate-specific antigen (PSA), and clinical stage are the currently established pretreatment prognostic parameters. Although these parameters are linked to cancer aggressiveness, the distinction between indolent and aggressive prostate cancer is difficult for the individual patient. Molecular marker may enable a better prediction of prostate cancer aggressiveness in the future.

\footnotetext{
* Correspondence: r.simon@uke.de

${ }^{+}$Marie-Christine Heinrich and Cosima Göbel contributed equally to this work. 1 Institute of Pathology, University Medical Center Hamburg-Eppendorf, Martinistrasse 52, D-20246 Hamburg, Germany

Full list of author information is available at the end of the article
}

Prostate stem cell antigen (PSCA) is a protein of unknown function anchored to the cell surface. It was discovered in an attempt to identify genes up regulated in human prostate cancer [2]. Though the name implies specificity for the prostate, PSCA is expressed in several tissues: Placenta, kidney, pancreas, and bladder [3-5]. The function of PSCA has not been fully elucidated [6-9]. Experiments suggest a possible role in cell adhesion, proliferation control and cell survival [2, 10]. Evidence is accumulating that - depending on the cell type involved - PSCA can have a tumor promoting or a tumor suppressive effect [11-15]. For example, loss of PSCA was associated with poor outcome in cancer of the gallbladder and stomach $[12,16]$, but with improved prognosis in pancreatic adenocarcinoma, renal cell carcinoma and non-small lung cancer [17-20]. The part of PSCA in prostate cancer remains unclear. Even if most available data suggest that prostate cancer may belong to the tumors with an oncogenic function of PSCA overexpression [21-24], there are

(c) The Author(s). 2018 Open Access This article is distributed under the terms of the Creative Commons Attribution 4.0 International License (http://creativecommons.org/licenses/by/4.0/), which permits unrestricted use, distribution, and reproduction in any medium, provided you give appropriate credit to the original author(s) and the source, provide a link to the Creative Commons license, and indicate if changes were made. The Creative Commons Public Domain Dedication waiver (http://creativecommons.org/publicdomain/zero/1.0/) applies to the data made available in this article, unless otherwise stated. 
also studies that do not support such a conclusion [25] or suggest the opposite that prostate cancer aggressiveness and metastasis is driven by PSCA down regulation [26-29].

To clarify the prognostic role of PSCA expression in prostate cancer, we analyzed PSCA expression by immunohistochemistry on a large preexisting tissue micro array (TMA).

\section{Methods}

\section{Patients}

Radical prostatectomy specimens were from 13,660 consecutive patients operated between 1992 and 2014 at the University Medical Center Hamburg-Eppendorf (Department of Urology and Martini Clinic). In addition to the classical Gleason categories, "quantitative" Gleason grading was performed as described elsewhere [30]. Follow-up was available for 12,208 patients (Table 1). In Kaplan-Meier analysis prostate specific antigen (PSA) recurrence was defined as the time point when postoperative PSA was at least $0.2 \mathrm{ng} / \mathrm{ml}$.

\section{Immunochemistry}

TMAs were manufactured as described [31]. Rabbit polyclonal antibody specific for PSCA (cat\#PA1-38516, Thermo scientific, dilution $1: 150$ ) was applied at $37{ }^{\circ} \mathrm{C}$ for $60 \mathrm{~min}$. Bound antibody was visualized with the EnVision Kit (Dako, Glostrup, Denmark). Staining was membranous and cytoplasmic in cancer and negative in normal tissue (Fig. 1). PSCA staining was typically found in either all $(100 \%)$ or none $(0 \%)$ of the cells in a cancer spot. Staining intensity was semi-quantitatively assessed by visual examination of the stained slides under a microscope and grouped into four categories: Examples of negative, weak, moderate and strong staining are in Fig. 1.

\section{Statistics}

To study association between PSCA expression and clinico-pathological variables, contingency tables were calculated and tested with the chi-square (likelihood) method. Analysis of variance and F-test was applied to find associations between PSCA expression and tumor cell proliferation. Kaplan-Meier curves were generated for PSA recurrence-free survival. Differences were checked by the log-rank test. Cox proportional hazards regression analysis was performed to test for independence and significance between pathological, molecular, and clinical variables. All calculations were done with JMP 11 (SAS Institute Inc., NC, USA).

\section{Results}

A total of 9642 (70.6\%) of TMA spots were interpretable. Non-informative cases (4023 spots; 29.4\%) lacked tissue samples or unequivocal cancer tissue spots. PSCA staining was absent in glands, stromal tissue and inflammatory cells of the normal prostate. In cancers, positive PSCA staining was seen in 5581 of our 9642 (53.7\%) interpretable tumors
Table 1 Pathological and clinical data of the arrayed prostate cancers

\begin{tabular}{|c|c|c|}
\hline & $\begin{array}{l}\text { Study cohort on } \\
\text { TMA }(n=13,660)\end{array}$ & $\begin{array}{l}\text { Biochemical relapse } \\
\text { among category }\end{array}$ \\
\hline \multicolumn{3}{|l|}{ Follow-up } \\
\hline$n$ & 12,208 & $3017(25 \%)$ \\
\hline Mean / median & 58.8 / 48.5 months & - \\
\hline \multicolumn{3}{|l|}{ Age (y) } \\
\hline$\leq 50$ & 352 & $61(17 \%)$ \\
\hline $51-59$ & 3335 & $701(21 \%)$ \\
\hline $60-69$ & 7827 & $1747(22 \%)$ \\
\hline$\geq 70$ & 2093 & $508(24 \%)$ \\
\hline \multicolumn{3}{|c|}{ Pretreatment PSA (ng/ml) } \\
\hline$<4$ & 1694 & $252(15 \%)$ \\
\hline $4-10$ & 8195 & $1464(18 \%)$ \\
\hline $10-20$ & 2763 & 847 (31\%) \\
\hline$>20$ & 922 & $442(48 \%)$ \\
\hline \multicolumn{3}{|c|}{ pT stage (AJCC 2002) } \\
\hline pT2 & 8861 & $1030(12 \%)$ \\
\hline рT3а & 2984 & $958(32 \%)$ \\
\hline pT3b & 1696 & $976(58 \%)$ \\
\hline pT4 & 71 & $53(75 \%)$ \\
\hline \multicolumn{3}{|l|}{ Gleason grade } \\
\hline$\leq 3+3$ & 2888 & $236(8 \%)$ \\
\hline $3+4$ & 7286 & $1269(17 \%)$ \\
\hline $3+4$ Tertiary 5 & 573 & $133(23 \%)$ \\
\hline $4+3$ & 1301 & $594(46 \%)$ \\
\hline $4+3$ Tertiary 5 & 868 & $380(44 \%)$ \\
\hline$\geq 4+4$ & 733 & $404(55 \%)$ \\
\hline \multicolumn{3}{|l|}{ Nodal (pN) stage } \\
\hline pNO & 7904 & $1896(24 \%)$ \\
\hline $\mathrm{pN}+$ & 856 & $524(61 \%)$ \\
\hline \multicolumn{3}{|c|}{ Surgical margin (R) status } \\
\hline Negative & 10,962 & 1939 (18\%) \\
\hline Positive & 2649 & $1078(41 \%)$ \\
\hline
\end{tabular}

NOTE: Numbers do not always add up to 13,660 in the different categories because of cases with missing data. Abbreviation: AJCC American Joint Committee on Cancer

and was considered weak in $22.4 \%$, moderate in $24.5 \%$ and strong in $6.8 \%$ of cancers. 4461 tumors $(46.3 \%)$ showed no PSCA staining.

\section{PSCA expression and tumor phenotype}

Absence of PSCA expression was linked to advanced pathological tumor stage $(p<0.0001)$, high Gleason grade $(p<0.0001)$, lymph node metastases $(p<0.0001)$, 


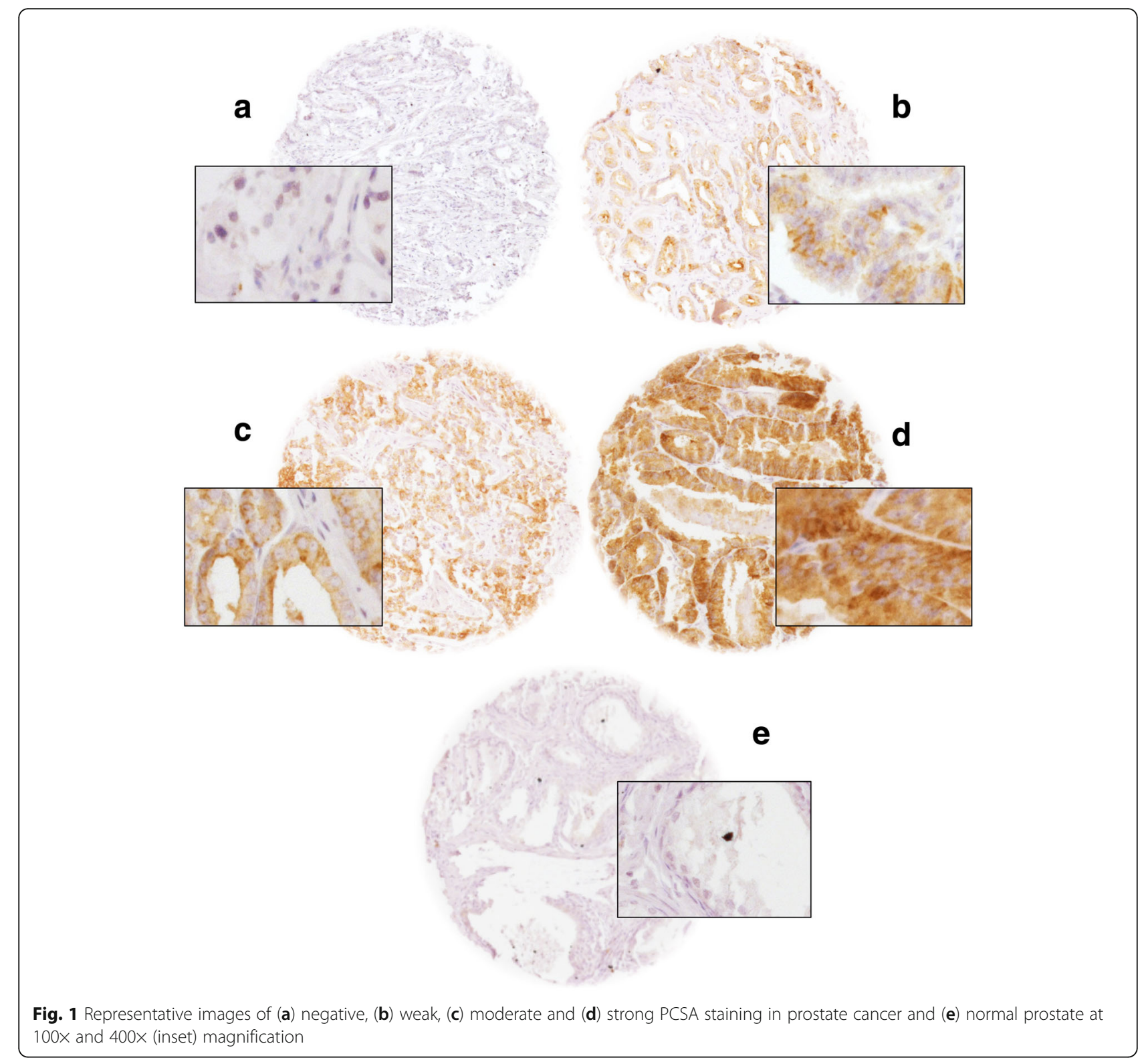

preoperative PSA level $(p=0.0118)$ and positive surgical margin $(p<0.0001)$. Data are summarized in Table 2.

\section{PSCA expression and TMPRSS2:ERG fusion}

Because TMPRSS2:ERG fusion is the predominant genetic marker in prostate cancer we analyzed its relation to PSCA expression [32]. Data on TMPRSS2:ERG fusion status obtained by FISH were available from 5241 and by immunohistochemistry (IHC) from 7762 tumors with evaluable PSCA staining. Data on both ERG FISH and IHC were available from 5042 cancers, and an identical result (ERG IHC positive and break by FISH or ERG IHC negative and missing break by FISH) was found in
95\% cancers. PSCA staining did not differ significantly between ERG positive and ERG negative cancers (Fig. 2).

\section{Association with other key genomic deletion}

Earlier studies had provided evidence for distinct molecular subgroups of prostate cancer defined by TMPRSS2:ERG fusion and several genomic deletions [32-37]. Therefore PSCA expression was compared with preexisting data on 10q23 (PTEN), 3p13 (FOXP1), 6q15 (MAP3K7), and 5q21 (CHD1) deletion. PSCA expression did not differ notably between cancers with and without these deletions with the exception of marginal association of positive PSCA 
Table 2 Association between PSCA staining and prostate cancer phenotype

\begin{tabular}{|c|c|c|c|c|c|c|}
\hline \multirow[b]{2}{*}{ Parameter } & \multirow{2}{*}{$\begin{array}{l}\text { Evaluable } \\
(\mathrm{N})\end{array}$} & \multicolumn{4}{|c|}{ PSCA staining (\%) } & \multirow[b]{2}{*}{ P } \\
\hline & & Negative & Weak & Moderate & Strong & \\
\hline Total & 9642 & 46.3 & 22.4 & 24.5 & 6.8 & \\
\hline \multicolumn{7}{|l|}{ Tumor stage } \\
\hline pT2 & 6003 & 41.5 & 23.6 & 26.9 & 8.0 & \multirow[t]{3}{*}{$<0.0001$} \\
\hline рT3a & 2269 & 51.1 & 20.9 & 22.5 & 5.5 & \\
\hline pT3b-pT4 & 1326 & 59.7 & 19.5 & 17.0 & 3.8 & \\
\hline \multicolumn{7}{|l|}{ Gleason grade } \\
\hline$\leq 3+3$ & 1713 & 47.0 & 23.0 & 22.8 & 7.2 & \multirow[t]{6}{*}{$<0.0001$} \\
\hline $3+4$ & 5275 & 43.4 & 22.8 & 26.5 & 7.4 & \\
\hline $3+4$ Tertiary 5 & 441 & 46.3 & 23.6 & 23.8 & 6.3 & \\
\hline $4+3$ & 977 & 50.2 & 21.2 & 21.8 & 6.9 & \\
\hline $4+3$ Tertiary 5 & 666 & 48.6 & 22.8 & 23.7 & 4.8 & \\
\hline$\geq 4+4$ & 562 & 61.6 & 17.4 & 17.8 & 3.2 & \\
\hline \multicolumn{7}{|c|}{ Lymph node metastasis } \\
\hline No & 5873 & 46.0 & 22.4 & 24.4 & 7.2 & \multirow[t]{2}{*}{$<0.0001$} \\
\hline $\mathrm{N}+$ & 674 & 59.9 & 19.1 & 17.7 & 3.3 & \\
\hline \multicolumn{7}{|c|}{ Preoperative PSA level (ng/ml) } \\
\hline$<4$ & 1099 & 48.6 & 19.7 & 25.3 & 6.4 & \multirow[t]{4}{*}{0.0118} \\
\hline $4-10$ & 5715 & 44.9 & 23.4 & 24.7 & 7.0 & \\
\hline $10-20$ & 1995 & 46.9 & 21.8 & 24.1 & 7.3 & \\
\hline$>20$ & 724 & 51.2 & 20.0 & 23.6 & 5.1 & \\
\hline \multicolumn{7}{|l|}{ Surgical margin } \\
\hline Negative & 7544 & 45.1 & 22.8 & 24.8 & 7.3 & \multirow[t]{2}{*}{$<0.0001$} \\
\hline Positive & 1882 & 51.3 & 20.8 & 22.6 & 5.3 & \\
\hline
\end{tabular}

expression and $6 \mathrm{q} 15-(p=0.0318)$ respective $3 \mathrm{p} 13-\mathrm{de}-$ letion ( $p=0.0019$, Fig. 3$)$.

\section{Tumor cell proliferation}

No association was found between PSCA staining and tumor cell proliferation as measured by Ki67 labeling index $(p=0.2211)$, neither in all cancers nor in subsets of ERG negative or ERG positive cancer, or in tumor subsets with identical Gleason score ( $p>0.05$; data not shown).

\section{Association with PSA recurrence}

Follow-up data were available from 8410 patients with interpretable PSCA staining. Tumors with negative PSCA staining showed a significantly shortened PSA recurrence-free interval compared with positively stained cancers $(p<0.0001$, Fig. 4). This holds true for the subgroup of ERG fusion negative and positive cancer (data not shown). In further analysis weak, moderate and strong stained tumors were grouped as positive. PSCA expression provided additional prognostic impact in most subsets of cancer with identical classical Gleason grade group $(p=0.0346$ for $\leq 3+$ $3, p=0.0206$ for $3+4, p=0.0092$ for $4+3$ and $p=0.4423$ for $\geq 4+4$, Fig. 5). However, the prognostic impact of PSCA expression was lost in subgroups with comparable quantitative Gleason scores (Additional file 1: Figure S1).

\section{Multivariate analysis}

Four different multivariate scenarios were used to simulate clinical decisions (Table 3). Scenario 1 evaluated the preoperatively available parameters: Preoperative Gleason grade obtained on the original biopsy, clinical tumor stage (cT stage) and preoperative PSA together with the postoperatively obtained PSCA expression. In scenario 2, the radical prostatectomy Gleason grade replaced the biopsy Gleason grade, while in scenario 3 pathological (pT) stage and surgical margin $(\mathrm{R})$ status replaced $\mathrm{cT}$ stage. In scenario 4 , the lymph node $(\mathrm{pN})$ stage is added. Overall, PSCA expression proved to be an independent favorable prognostic parameter. The Cox hazard ratio for PSA recurrence-free survival after radical prostatectomy between weak and negative PSCA expression varied from 0.84 to 0.93 and was significant in scenario 1 and 2 (Table 3).

\section{Discussion}

This study demonstrates that PSCA expression is significantly associated with favorable tumor phenotype and a 


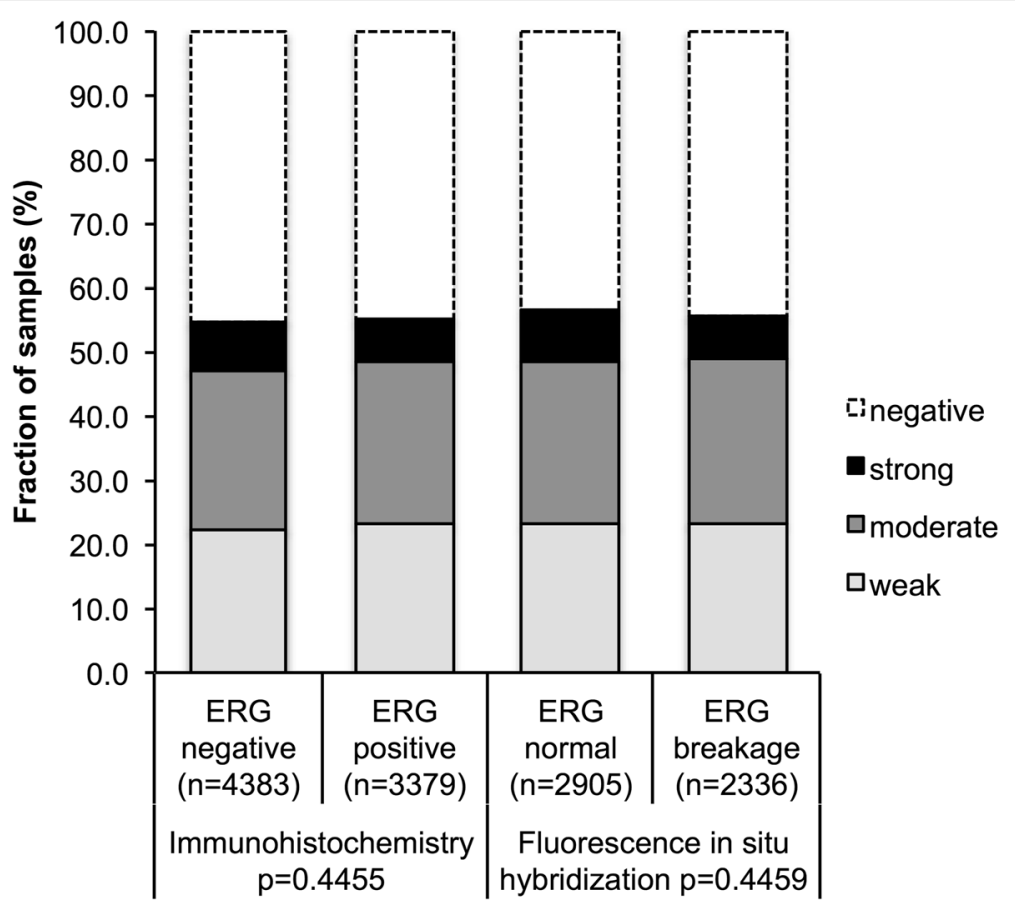

Fig. 2 No association between PSCA staining and ERG status neither when the latter was determined by immunohistochemistry nor by fluorescence in-situ hybridization; Breakage indicates rearrangement of the ERG gene

reduced risk for PSA recurrence. A total of $54 \%$ of prostate cancers showed detectable PSCA expression in our IHC study. This is in the range of two other studies reporting in $88 \%$ of 126 [2] or $48 \%$ of 233 patients [4] IHC positivity. These IHC findings are not contradictory to further studies describing at least a low level PSCA expression in all prostate cancers utilizing polymerase chain reaction [5, 23]. It is well known that IHC negativity does not reflect the absence of expression but rather that a certain threshold for detection is not reached. The threshold of detection is greatly influenced by the IHC protocol [38]. Although Ross et al. [4] and Reiter et al. [2] used different antibodies and protocols; they obviously resulted in a comparable sensitivity as in our study. We consider our protocol suited for studying the prognostic impact of PSCA expression as the selected conditions enable a distinction of cancers with high and low levels of PSCA

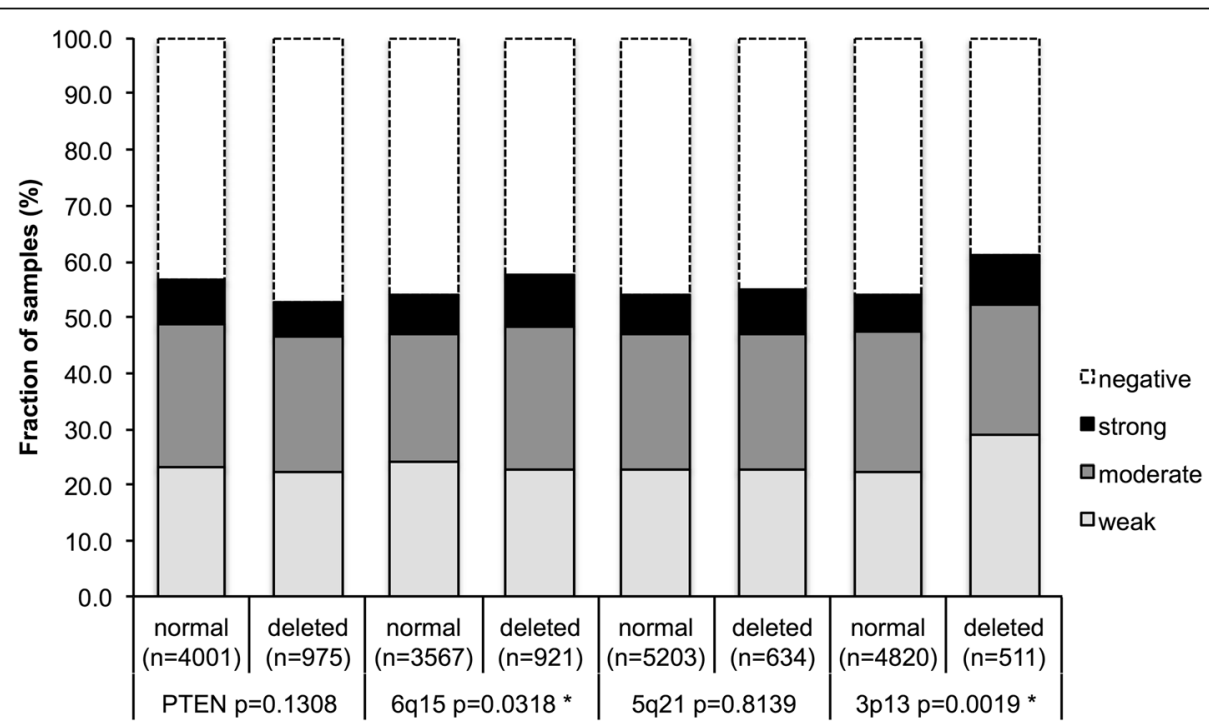

Fig. 3 Association analysis between negative versus positive (weak + moderate + strong) PSCA expression and deletion of 10q23 (PTEN), 6q15 (MAP3K7), 5q21 (CHD1) and 3p13 (FOXP1). *Asterisk denotes significant $p$-value 


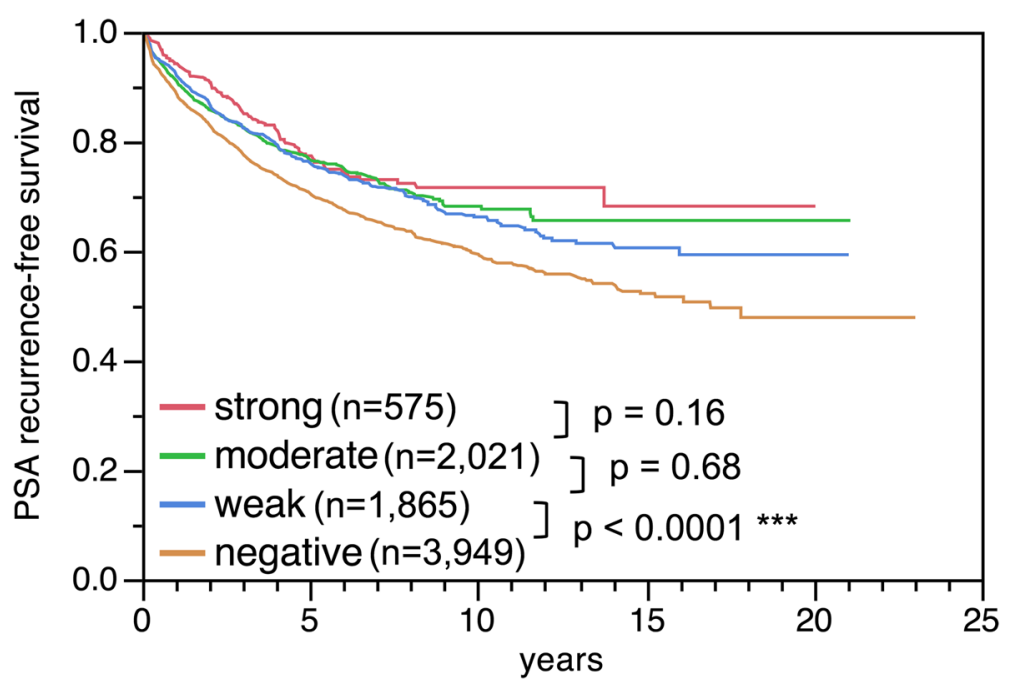

Fig. 4 Kaplan-Meier analysis of prostate specific antigen (PSA) recurrence after radical prostatectomy and negative versus weak, moderate and strong PSCA expression. *Asterisk denotes significant $p$-value

expression. Given that normal prostate epithelial cells usually did not stain for PSCA, we assume that PSCA up-regulation had occurred in a fraction of prostate cancers. The link between cancer specific up-regulation of a protein and better prognosis is uncommon and argues for a "protective" or tumor suppressive role. Our outcomes are in concordance with data from Larkin et al. [27], also reporting a link between elevated PSCA expression and favorable clinical course. A tumor suppressive role of high level PSCA expression is also supported from cell line models. For example, functional analysis of cell lines from gastric and gallbladder cancer demonstrated that forced overexpression of PSCA hampered cell proliferation $[12,16]$.
It is noteworthy that several investigators reported contrary results. IHC with various and partly custom made antibodies to conventional large sections of 40 [22] and 112 [5] prostate cancers revealed associations with high Gleason score, advanced stage and castration resistant disease. Also in TMA studies including 114 [23] and 246 [24] prostate cancers the authors reported associations between strong PSCA expression and high Gleason score. However, another TMA study on 64 prostate cancers could not confirm these findings [25]. We cannot explain the discrepancy between these studies and our data obtained on almost 10,000 successfully analyzed carcinoma.

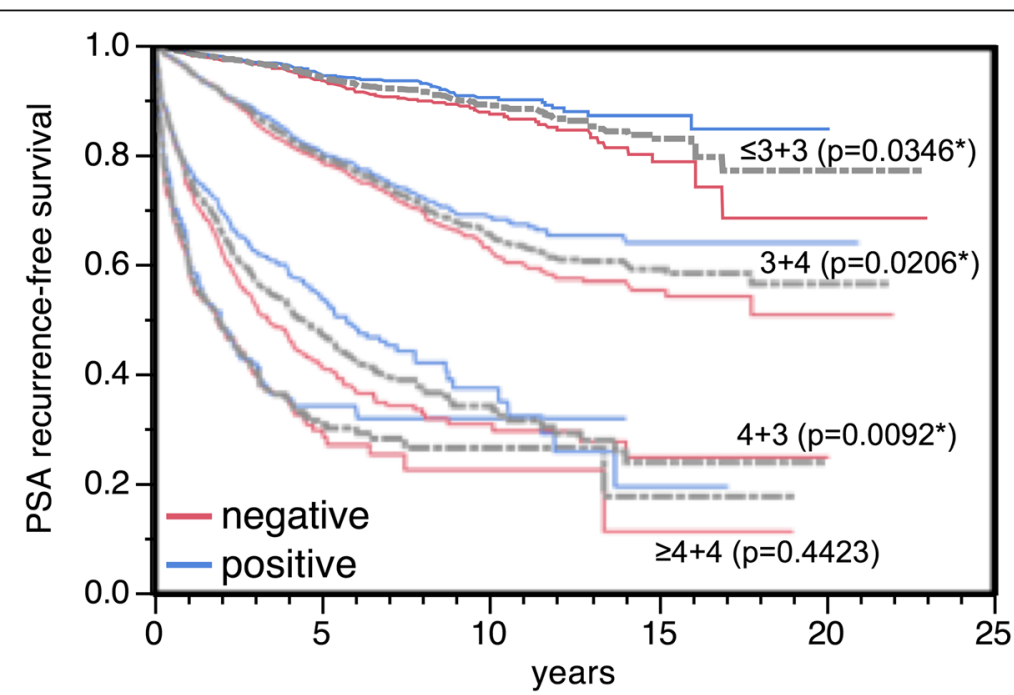

Fig. 5 Kaplan-Meier plot of PSA recurrence-free survival and negative or positive (weak + moderate + strong) PSCA expression stratified for Gleason grade $(\leq 3+3, n=1535 ; 3+4, n=3430 ; 4+3, n=984 ; \geq 4+4, n=323)$. *Asterisk denotes significant $p$-value 
Table 3 Hazard ratios of established prognostic parameters and PSCA expression in prostate cancer

\begin{tabular}{|c|c|c|c|c|}
\hline Scenario & 1 & 2 & 3 & 4 \\
\hline Analyzable (N) & 8334 & 8454 & 8570 & 5801 \\
\hline \multicolumn{5}{|l|}{ Gleason grade biopsy } \\
\hline $3+4$ vs. $\leq 3+3$ & $1.94^{* * *}$ & & & \\
\hline $4+3$ vs. $3+4$ & $1.63^{* * *}$ & & & \\
\hline$\geq 4+4$ vs. $4+3$ & $1.39 * * *$ & & & \\
\hline \multicolumn{5}{|l|}{ CT stage } \\
\hline T2a vs. T1c & $1.53^{* * *}$ & $1.47^{* * *}$ & & \\
\hline T3a vs. T2c & $0.65^{*}$ & 1.07 & & \\
\hline \multicolumn{5}{|l|}{ Preoperative PSA level } \\
\hline $4-10$ vs. $<4$ & $1.25^{*}$ & $1.21^{*}$ & 1.11 & 1.14 \\
\hline $10-20$ vs. $4-10$ & $1.58^{* * *}$ & $1.41^{* * *}$ & $1.25^{* * *}$ & $1.16^{*}$ \\
\hline$>20$ vs. $10-20$ & $1.67^{* * *}$ & $1.47^{* * *}$ & $1.23^{*}$ & $1.22^{*}$ \\
\hline \multicolumn{5}{|l|}{ PSCA expression } \\
\hline Positive vs. negative & $0.84^{* * *}$ & $0.86^{* *}$ & 0.93 & 0.93 \\
\hline \multicolumn{5}{|l|}{$\begin{array}{l}\text { Gleason grade } \\
\text { prostatectomy }\end{array}$} \\
\hline $3+4$ vs. $\leq 3+3$ & & $2.91^{* * *}$ & $2.39^{* * *}$ & $2.30^{* * *}$ \\
\hline $4+3$ vs. $3+4$ & & $2.72^{* * *}$ & $2.24^{* * *}$ & $2.05^{* * *}$ \\
\hline$\geq 4+4$ vs. $4+3$ & & $1.75^{* * *}$ & $1.25^{*}$ & $1.21^{*}$ \\
\hline \multicolumn{5}{|l|}{ pT stage } \\
\hline T3a vs. T2 & & & $1.94^{* * *}$ & $1.94^{* * *}$ \\
\hline T3b vs. T3a & & & $1.73^{* * *}$ & $1.52^{* * *}$ \\
\hline T4 vs. T3b & & & 1.20 & 1.24 \\
\hline \multicolumn{5}{|l|}{$\begin{array}{l}\text { Surgical margin } \\
\text { (R) status }\end{array}$} \\
\hline R1 vs. R0 & & & $1.40^{* * *}$ & $1.18^{*}$ \\
\hline \multicolumn{5}{|l|}{ Nodal (pN) stage } \\
\hline $\mathrm{N}+$ vs. NO & & & & $1.56^{* * *}$ \\
\hline
\end{tabular}

Scenario 1 combines preoperatively available parameter (preoperative Gleason grade obtained on the original biopsy, clinical tumor (cT) stage, and preoperative PSA) with the postoperative PSCA expression. In scenario 2 the biopsy Gleason is replaced by the Gleason grade obtained on radical prostatectomy. In scenario $3 \mathrm{cT}$ stage is superseded by pathological tumor (pT) stage and surgical margin (R) status. In scenario 4 the lymph node $(\mathrm{pN})$ stage is added. Asterisk indicate significance level: ${ }^{*} p \leq 0.05$, ${ }^{* *} p \leq 0.001$, and *** $p \leq 0.0001$

The mechanism for a tumor suppressive function of PSCA is unknown. In our study, we compared the expression of PSCA with molecular attributes associated with genomic instability, chromosomal deletion and tumor cell proliferation [37]. We found previously that features with a role in cell cycle control (p16 [39] or APE1 [40]) were significantly associated with a high Ki67 labeling index. Molecular attributes linked to genomic instability (MSH6/ PMS2/MLH1 [41], ELAV1 [42], or HOOK3 [43]) were found to be associated with chromosomal deletion. The lack of clear-cut association with these features argues against a relevant impact of PSCA on cell proliferation control and development of deletion in prostate cancer. This is in contrast to one experimental study, suggesting an accelerating effect of PSCA loss on cell proliferation in a gastric cancer cell line [16]. That PSCA expression was completely unrelated to TMPRSS2:ERG fusion further demonstrates that PSCA is not significantly affected by any of the hundreds of genes that are deregulated in ERG fusion positive prostate cancer [44-47].

PSCA expression was significantly associated with favorable patient outcome in our cohort. A possible clinical relevance of this finding is supported by its statistical independence of classical prognostic markers, especially in a pre-operative disease state. However, in comparison with established features such as the Gleason score, the impact of PSCA expression on patient outcome was rather small. If traditional prognostic Gleason groups were used, a small prognostic impact was still found in Gleason $3+4$ $(p=0.0206)$ or Gleason $4+3 \quad(p=0.0092)$. However, if these subgroups were further differentiated according to the fraction of Gleason 4 (quantitative Gleason grading [30]) these PSCA associated prognostic differences vanished. This further illustrates the high bar that molecular characteristics have to overcome if compared with optimized morphologic analysis.

\section{Conclusions}

PSCA expression is a statistically independent predictor of favorable prognosis in prostate cancer. Although its prognostic impact per se is not very strong, PSCA expression analysis could be considered for inclusion in multi-parametric prognostic tests to distinguish prostate cancers with need for radical therapy.

\section{Additional file}

Additional file 1: Figure S1. Kaplan-Meier plot of prostate specific antigen (PSA) recurrence and PSCA expression stratified for quantitative Gleason grade. Note the different time scale for Gleason Tertiary 5 grades. (DOC $2467 \mathrm{~kb})$

\section{Abbreviations}

AR: Androgen receptor; CHD1: Chromodomain-Helicase-DNA-Binding Protein 1; ELAV1: Embryonic Lethal, Abnormal Vision, Drosophila)-Like 1; FISH: Fluorescence in-situ hybridization; FOXP1: Forkhead box protein P1; HOOK3: Hook Microtubule Tethering Protein 3; IHC: Immunohistochemistry; MAP3K: Mitogen-Activated Protein Kinase Kinase Kinase 7; PSCA: Prostate stem cell antigen; PSA: Prostate specific antigen; PTEN: Phosphatase and tensin homolog; RPE: Radical prostatectomy; TMPRSS2: Transmembrane protease, serine 2; ERG: ETS-related gene fusion; TMA: Tissue microarray

\section{Acknowledgements}

We thank Julia Schumann, Sünje Seekamp and Inge Brandt for excellent technical assistance.

Availability of data and materials

All data generated or analyzed during this study are included in this published article [and its Additional file 1]. 


\section{Authors' contributions}

$\mathrm{MCH}, \mathrm{AH}, \mathrm{RS}$, and $\mathrm{GS}$ designed the study, and drafted the manuscript. $\mathrm{HH}$, $M G, C B$ and TS participated in study design. $M C H, A H, C G, C S 1, C S 2$ performed $\mathrm{IHC}$ analysis and scoring. PL and EB participated in pathology data analysis. CH-M and RS performed statistical analysis. TS, CK, MK, MCH, $\mathrm{HH} 2$ and $\mathrm{AH}$ participated in data interpretation, and helped to draft the manuscript. All authors read and approved the final manuscript.

\section{Ethics approval and consent to participate}

The ethics committee of the Ärztekammer Hamburg approved this study (WF-049/09 and PV3652). According to local laws (HmbKHG, \$12,1) informed consent was not required for this study.

\section{Competing interests}

The authors declare that they have no competing interests.

\section{Publisher's Note}

Springer Nature remains neutral with regard to jurisdictional claims in published maps and institutional affiliations.

\section{Author details}

'Institute of Pathology, University Medical Center Hamburg-Eppendorf, Martinistrasse 52, D-20246 Hamburg, Germany. ${ }^{2}$ Institute of Neuropathology, University Medical Center Hamburg-Eppendorf, Martinistrasse 52, D-20246 Hamburg, Germany. ${ }^{3}$ Department of Surgery, University Medical Center Hamburg-Eppendorf, Martinistrasse 52, D-20246 Hamburg, Germany. ${ }^{4}$ Martini-Clinic, Prostate Cancer Center, University Medical Center Hamburg-Eppendorf, Martinistrasse 52, D-20246 Hamburg, Germany. ${ }^{5}$ Department of Urology, Section for translational Prostate Cancer Center, University Medical Center Hamburg-Eppendorf, Martinistrasse 52, D-20246 Hamburg, Germany.

\section{Received: 11 October 2017 Accepted: 22 May 2018}

\section{Published online: 31 May 2018}

\section{References}

1. Torre LA, Bray F, Siegel RL, Ferlay J, Lortet-Tieulent J, Jemal A. Global cancer statistics, 2012. CA Cancer J Clin. 2015;65(2):87-108.

2. Reiter RE, Gu Z, Watabe T, Thomas G, Szigeti K, Davis E, Wahl M, Nisitani S, Yamashiro J, Le Beau MM, et al. Prostate stem cell antigen: a cell surface marker overexpressed in prostate cancer. Proc Natl Acad Sci U S A. 1998; 95(4):1735-40

3. Cunha AC, Weigle B, Kiessling A, Bachmann M, Rieber EP. Tissue-specificity of prostate specific antigens: comparative analysis of transcript levels in prostate and non-prostatic tissues. Cancer Lett. 2006;236(2):229-38.

4. Ross S, Spencer SD, Holcomb I, Tan C, Hongo J, Devaux B, Rangell L, Keller GA, Schow P, Steeves RM, et al. Prostate stem cell antigen as therapy target: tissue expression and in vivo efficacy of an immunoconjugate. Cancer Res. 2002;62(9):2546-53.

5. Gu Z, Thomas G, Yamashiro J, Shintaku IP, Dorey F, Raitano A, Witte ON, Said JW, Loda M, Reiter RE. Prostate stem cell antigen (PSCA) expression increases with high Gleason score, advanced stage and bone metastasis in prostate cancer. Oncogene. 2000;19(10):1288-96.

6. Saeki N, Gu J, Yoshida T, Wu X. Prostate stem cell antigen: a Jekyll and Hyde molecule? Clin Cancer Res. 2010;16(14):3533-8

7. Raff AB, Gray A, Kast WM. Prostate stem cell antigen: a prospective therapeutic and diagnostic target. Cancer Lett. 2009;277(2):126-32.

8. Esfahani M, Ataei N, Panjehpour M. Biomarkers for evaluation of prostate cancer prognosis. Asian Pac J Cancer Prev. 2015;16(7):2601-11.

9. Tricoli JV, Schoenfeldt M, Conley BA. Detection of prostate cancer and predicting progression: current and future diagnostic markers. Clin Cancer Res. 2004;10(12 Pt 1):3943-53

10. Kim SH, Park WS, Kim SH, Park B, Joo J, Lee GK, Joung JY, Seo HK, Chung J, Lee $\mathrm{KH}$. Prostate stem cell antigen expression in radical prostatectomy specimens predicts early biochemical recurrence in patients with high risk prostate Cancer receiving Neoadjuvant hormonal therapy. PLoS One. 2016; 11(3):e0151646.

11. Zhang LY, Wu JL, Qiu HB, Dong SS, Zhu YH, Lee VH, Qin YR, Li Y, Chen J, Liu $H B$, et al. PSCA acts as a tumor suppressor by facilitating the nuclear translocation of RB1CC1 in esophageal squamous cell carcinoma. Carcinogenesis. 2016;37(3):320-32.
12. Ono H, Hiraoka N, Lee YS, Woo SM, Lee WJ, Choi IJ, Saito A, Yanagihara K, Kanai Y, Ohnami S, et al. Prostate stem cell antigen, a presumable organdependent tumor suppressor gene, is down-regulated in gallbladder carcinogenesis. Genes Chromosomes Cancer. 2012;51(1):30-41.

13. Saeki $\mathrm{N}$, Ono H, Sakamoto H, Yoshida T. Down-regulation of immunerelated genes by PSCA in gallbladder Cancer cells implanted into mice. Anticancer Res. 2015;35(5):2619-25.

14. Wang L, Sang Y, Tang J, Zhang RH, Luo D, Chen M, Deng WG, Kang T. Down-regulation of prostate stem cell antigen (PSCA) by slug promotes metastasis in nasopharyngeal carcinoma. J Pathol. 2015;237(4):411-22.

15. Zhigang Z, Wenlv S. Prostate stem cell antigen (PSCA) expression in human prostate cancer tissues: implications for prostate carcinogenesis and progression of prostate cancer. Jpn J Clin Oncol. 2004;34(7):414-9.

16. Study Group of Millennium Genome Project for C, Sakamoto H, Yoshimura K, Saeki N, Katai H, Shimoda T, Matsuno Y, Saito D, Sugimura H, Tanioka F, et al. genetic variation in PSCA is associated with susceptibility to diffusetype gastric cancer. Nat Genet. 2008;40(6):730-40.

17. Amara N, Palapattu GS, Schrage M, Gu Z, Thomas GV, Dorey F, Said J, Reiter RE. Prostate stem cell antigen is overexpressed in human transitional cell carcinoma. Cancer Res. 2001;61(12):4660-5.

18. Argani P, Rosty C, Reiter RE, Wilentz RE, Murugesan SR, Leach SD, Ryu B, Skinner HG, Goggins M, Jaffee EM, et al. Discovery of new markers of cancer through serial analysis of gene expression: prostate stem cell antigen is overexpressed in pancreatic adenocarcinoma. Cancer Res. 2001;61(11):4320-4.

19. Elsamman EM, Fukumori T, Tanimoto S, Nakanishi R, Takahashi M, Toida K, Kanayama HO. The expression of prostate stem cell antigen in human clear cell renal cell carcinoma: a quantitative reverse transcriptase-polymerase chain reaction analysis. BJU Int. 2006;98(3):668-73.

20. Kawaguchi T, Sho M, Tojo T, Yamato I, Nomi T, Hotta K, Hamada K, Suzaki Y, Sugiura S, Kushibe K, et al. Clinical significance of prostate stem cell antigen expression in non-small cell lung cancer. Jpn J Clin Oncol. 2010;40(4):319-26.

21. Gu X, Ma Y, Xiao J, Zheng H, Song C, Gong Y, Xing X. Up-regulated biglycan expression correlates with the malignancy in human colorectal cancers. Clin Exp Med. 2012;12(3):195-9.

22. Ruan Y, Yu W, Cheng F, Zhang X, Larre S. Detection of prostate stem cell antigen expression in human prostate cancer using quantum-dot-based technology. Sensors (Basel). 2012;12(5):5461-70.

23. Taeb J, Asgari M, Abolhasani M, Farajollahi MM, Madjd Z. Expression of prostate stem cell antigen (PSCA) in prostate cancer: a tissue microarray study of Iranian patients. Pathol Res Pract. 2014;210(1):18-23.

24. Han KR, Seligson DB, Liu X, Horvath S, Shintaku PI, Thomas GV, Said JW, Reiter RE. Prostate stem cell antigen expression is associated with Gleason score, seminal vesicle invasion and capsular invasion in prostate cancer. J Urol. 2004;171(3):1117-21.

25. Joung JY, Yang SO, Jeong IG, Han KS, Seo HK, Chung J, Park WS, Lee KH. Reverse transcriptase-polymerase chain reaction and immunohistochemical studies for detection of prostate stem cell antigen expression in prostate cancer: potential value in molecular staging of prostate cancer. Int J Urol. 2007:14(7):635-43.

26. Fuessel S, Sickert D, Meye A, Klenk U, Schmidt U, Schmitz M, Rost AK, Weigle B, Kiessling A, Wirth MP. Multiple tumor marker analyses (PSA, hK2, PSCA, trp-p8) in primary prostate cancers using quantitative RT-PCR. Int J Oncol. 2003:23(1):221-8.

27. Larkin SE, Holmes S, Cree IA, Walker T, Basketter V, Bickers B, Harris S, Garbis SD, Townsend PA, Aukim-Hastie C. Identification of markers of prostate cancer progression using candidate gene expression. Br J Cancer. 2012;106(1):157-65.

28. Moore ML, Teitell MA, Kim Y, Watabe T, Reiter RE, Witte ON, Dubey P. Deletion of PSCA increases metastasis of TRAMP-induced prostate tumors without altering primary tumor formation. Prostate. 2008;68(2):139-51.

29. Schmidt U, Fuessel S, Koch R, Baretton GB, Lohse A, Tomasetti S, Unversucht $\mathrm{S}$, Froehner M, Wirth MP, Meye A. Quantitative multi-gene expression profiling of primary prostate cancer. Prostate. 2006;66(14):1521-34.

30. Sauter G, Steurer S, Clauditz TS, Krech T, Wittmer C, Lutz F, Lennartz M, Janssen T, Hakimi N, Simon R, et al. Clinical utility of quantitative Gleason grading in prostate biopsies and prostatectomy specimens. Eur Urol. 2016;69(4):592-8.

31. Mirlacher M, Simon R. Recipient block TMA technique. Methods Mol Biol. 2010;664:37-44

32. Tomlins SA, Rhodes DR, Perner S, Dhanasekaran SM, Mehra R, Sun XW, Varambally S, Cao X, Tchinda J, Kuefer R, et al. Recurrent fusion of TMPRSS2 and ETS transcription factor genes in prostate cancer. Science. 2005; 310(5748):644-8. 
33. Minner S, Enodien M, Sirma H, Luebke AM, Krohn A, Mayer PS, Simon R, Tennstedt P, Muller J, Scholz L, et al. ERG status is unrelated to PSA recurrence in radically operated prostate cancer in the absence of antihormonal therapy. Clin Cancer Res. 2011;17(18):5878-88.

34. Burkhardt L, Fuchs S, Krohn A, Masser S, Mader M, Kluth M, Bachmann F, Huland $H$, Steuber T, Graefen M, et al. CHD1 is a 5 q21 tumor suppressor required for ERG rearrangement in prostate cancer. Cancer Res. 2013;73(9):2795-805.

35. Kluth M, Hesse J, Heinl A, Krohn A, Steurer S, Sirma H, Simon R, Mayer PS, Schumacher U, Grupp K, et al. Genomic deletion of MAP3K7 at 6q12-22 is associated with early PSA recurrence in prostate cancer and absence of TMPRSS2:ERG fusions. Mod Pathol. 2013;26(7):975-83.

36. Krohn A, Seidel A, Burkhardt L, Bachmann F, Mader M, Grupp K, Eichenauer T, Becker A, Adam M, Graefen M, et al. Recurrent deletion of 3p13 targets multiple tumour suppressor genes and defines a distinct subgroup of aggressive ERG fusion-positive prostate cancers. J Pathol. 2013;231(1):130-41.

37. Minner S, Jessen B, Stiedenroth L, Burandt E, Kollermann J, Mirlacher M, Erbersdobler A, Eichelberg C, Fisch M, Brummendorf TH, et al. Low level HER2 overexpression is associated with rapid tumor cell proliferation and poor prognosis in prostate cancer. Clin Cancer Res. 2010;16(5):1553-60.

38. Schlomm T, Iwers L, Kirstein P, Jessen B, Kollermann J, Minner S, PassowDrolet A, Mirlacher M, Milde-Langosch K, Graefen M, et al. Clinical significance of p53 alterations in surgically treated prostate cancers. Mod Pathol. 2008;21(11):1371-8,

39. Burdelski C, Dieckmann T, Heumann A, Hube-Magg C, Kluth M, Beyer B, Steuber T, Pompe R, Graefen M, Simon R, et al. p16 upregulation is linked to poor prognosis in ERG negative prostate cancer. Tumour Biol. 2016;37(9): 12655-63.

40. Juhnke M, Heumann A, Chirico V, Hoflmayer D, Menz A, Hinsch A, HubeMagg C, Kluth M, Lang DS, Moller-Koop C, et al. Apurinic/apyrimidinic endonuclease 1 (APE1/Ref-1) overexpression is an independent prognostic marker in prostate cancer without TMPRSS2:ERG fusion. Mol Carcinog. 2017; 56(9):2135-45.

41. Wilczak W, Rashed S, Hube-Magg C, Kluth M, Simon R, Buscheck F, Clauditz TS, Grupp K, Minner S, Tsourlakis MC, et al. Up-regulation of mismatch repair genes MSH6, PMS2 and MLH1 parallels development of genetic instability and is linked to tumor aggressiveness and early PSA recurrence in prostate cancer. Carcinogenesis. 2017;38(1):19-27.

42. Melling N, Taskin B, Hube-Magg C, Kluth M, Minner S, Koop C, Grob T, Graefen M, Heinzer H, Tsourlakis MC, et al. Cytoplasmic accumulation of ELAVL1 is an independent predictor of biochemical recurrence associated with genomic instability in prostate cancer. Prostate. 2016;76(3):259-72.

43. Melling N, Harutyunyan L, Hube-Magg C, Kluth M, Simon R, Lebok P, Minner S, Tsourlakis MC, Koop C, Graefen M, et al. High-level HOOK3 expression is an independent predictor of poor prognosis associated with genomic instability in prostate Cancer. PLoS One. 2015;10(7):e0134614.

44. Brase JC, Johannes M, Mannsperger H, Falth M, Metzger J, Kacprzyk LA, Andrasiuk T, Gade S, Meister M, Sirma H, et al. TMPRSS2-ERG -specific transcriptional modulation is associated with prostate cancer biomarkers and TGF-beta signaling. BMC Cancer. 2011;11:507.

45. Gupta S, lljin K, Sara H, Mpindi JP, Mirtti T, Vainio P, Rantala J, Alanen K, Nees M, Kallioniemi O. FZD4 as a mediator of ERG oncogene-induced WNT signaling and epithelial-to-mesenchymal transition in human prostate cancer cells. Cancer Res. 2010;70(17):6735-45.

46. Jhavar S, Brewer D, Edwards S, Kote-Jarai Z, Attard G, Clark J, Flohr P, Christmas T, Thompson A, Parker M, et al. Integration of ERG gene mapping and gene-expression profiling identifies distinct categories of human prostate cancer. BJU Int. 2009;103(9):1256-69.

47. Taylor BS, Schultz N, Hieronymus H, Gopalan A, Xiao Y, Carver BS, Arora VK, Kaushik P, Cerami E, Reva B, et al. Integrative genomic profiling of human prostate cancer. Cancer Cell. 2010;18(1):11-22.

Ready to submit your research? Choose BMC and benefit from:

- fast, convenient online submission

- thorough peer review by experienced researchers in your field

- rapid publication on acceptance

- support for research data, including large and complex data types

- gold Open Access which fosters wider collaboration and increased citations

- maximum visibility for your research: over $100 \mathrm{M}$ website views per year

At BMC, research is always in progress.

Learn more biomedcentral.com/submissions 